\title{
A META-ANALYSIS OF ISLAMIC MICROFINANCE : CASE BASED EVIDENCE FROM INDIA
}

\author{
Mohammad Irfan \\ School of Business, Auro University, Surat, India, mohammad.irfan@aurouniversity.edu.in
}

\begin{abstract}
This study examines Islamic microfinance as an important contributor to both the economic and human development of India. We are aware that conventional microfinance products have flourished in India; however, these products do not fulfil the needs of all Muslim clients. Taking small glimpses of Islamic microfinance (IMF), we can say it is working successfully in Muslim countries. From the meta-analysis we classify the literature into seven categories, viz. social benefits, religious values, business enterprises, poverty alleviation, sustainable development, rural development and economic development. The contribution of research papers has risen across the literature review and there has been a sharp rise in new facts pertaining to Islamic microfinance in India. As a diagnostic check, all seven factors of the meta-analysis of IMF contain evidence for the case study of India. Bait-un-Nasr is an urban co-operative credit society, located in Mumbai, India that has practised all of the factors extracted by the meta-analysis. This paper provides a roster of emerging projects accompanied by a comprehensive review of literature that will be useful to both academicians and practitioners for studying existing research and contemporary future research.
\end{abstract}

Keywords: Islamic microfinance, Economic development, Human development, Content analysis. JEL Classification: G15; G21; O43; Z11.

Article history:

Received : October 16, 2019

Revised : December 18, 2019

Accepted : January 8, 2020

Available online : February 28, 2020

https://doi.org/10.21098/jimf.v6i1.1202 


\section{INTRODUCTION}

\subsection{Background}

The term micro-financing encompasses the provision of financial services such as micro credit, micro savings and micro insurance to poor people. The market mechanism can be productively used to improve the economic conditions of poor people. The concept of microfinance as a financial service that helps those who have no money, low-income individuals or groups is in fact very old. Small microcredit existed as far back as the early 1700s but nowadays is more well known in developing as opposed to developed countries. Surprisingly, the rate of default for loans is very low, with as many as 90 to 95 per cent of loans repaid (Kono \& Takahashi, 2010). The important aspect is that the interest rate is lower in comparison to that of a bank. The World Bank estimates that more than 650 million people have benefitted from microfinance either directly or indirectly (Obaidullah, 2008). To illustrate, India, as a developing country, has 63,000 commercial bank branches, 14,000 regional rural bank branches, and 100,000 cooperative bank branches, yet banking and finance continue to remain out of reach for millions. The issue is that more than 75 million households are dependent on money lenders and more than 90 per cent of the country's rural population has no access to institutional credit. Microfinance therefore has the potential to change the lives of millions of people.

The Consultative Group to Assist the Poor (CGAP) conducted a survey in 2011 aimed at better understanding the current supply of Islamic microfinance. Essentially, the highest rates of growth were found for products such Murabaha and Qard Hassan (Cost plus and benevolent loan).

Islamic microfinance is a new trend in microfinance and complies with Shariah laws and principles. Shariah sets out permissible and non-permissible sectors and information on commercial adherence. It involves halal projects which must be for the social empowerment and economic development of the country. However, the Indian government has not provided the same such instruction for Islamic finance, banking, insurance and microfinance. The reason for this is that most firms that work in Islamic microfinance in India are unregistered. India is a country in which the middle and lower classes make up the majority of the population. Islamic microfinance institutions work in the area of small savings for low wage earners. This assists them in developing the saving habits of a wage earner. It is also a small-scale type of investment. Islamic microfinance, in dealing with interest-free loans and loans against securities, saves people from the burden of interest.

Islamic microfinance is centred on a group-based credit approach, "One for All and All for One". Borrowers and creditors thus undertake their transactions based on this mutual concept. Grameen Bank, one of the best-known microfinance institutions, was founded in 1976 based on an idea by Muhammad Yunus (AjwaniRamchandani, 2017).

The world of Islamic microfinance is flourishing. A number of Islamic microfinance institutions exist to provide society with interest-free finance. Consequently, there are 164 institutions operating in East Asia and the Pacific, 72 in the Middle East and North Africa, 12 in South Africa, 4 in Sub Saharan Africa and 3 institutions in Europe and Central Asia (CGAP, 2008). 
Meanwhile, BMT (Baitul Maal wat Tamwil) is working on alleviating poverty in Indonesia. It is also attempting to provide easy access to microfinance funds. In working for the welfare of society, BMT seeks to uphold Shariah law in providing loans to society (Riwajanti, 2014). Zakat and waqt are integrated within the management of the Baitul Maal wat Tamwil (BMT ) Islamic financial cooperatives. BMT thus manages Islamic finance for the society while Baitul Tamwil works as a co-operative Islamic microfinance institution. There are currently more than 5,000 BMTs across Indonesia that help society either directly or indirectly (Salaam Gateway, 2019).

The current study focuses on extracting the factors of Islamic microfinance (IMF) in India by means of a meta-analysis of the given literature. This study is important for two reasons, namely so that investors can be aware of the impact of Islamic mircofinance on the society of India and to enable governments to take precautionary action to open IMF in nonbank financial companies (NBFCs) while also opening the window to Islamic finance in conventional banks to help prevent any possible financial downturn in the country, based on the mission of Islamic microfinance to help alleviate the poverty of the nation.

For this purpose, the researcher has performed a diagnostic analysis of a case study, namely that of Bait-un-Nasr from Mumbai (1976), India. Bait-unNasr provides interest-free loans to clients as well as undertaking other activities associated with Islamic finance. It practises all seven of the factors included in this study - economic development, social benefits, poverty alleviation, religious practices, business enterprises, sustainable development, and rural development.

Objectives

The objectives of this paper have been divided into two parts. First, to extract the factors of IMF by meta-analysis. Second, to practices of all factors of metaanalysis, evidence based case study on the Bait-un-Nasr Mumbai 1976 India .

\section{LITERATURE REVIEW}

\subsection{Background Theory}

For the content analysis by literature review, this session consists of theory that supports the research on microfinance and Islamic microfinance.

\subsubsection{Microfinance}

One of the major objectives of Islam is to support the needy, and Islamic microfinance works to fulfil this objective. In the current scenario, Islamic microfinance is flourishing in Indonesia, Bangladesh and Sudan. According to the CGAP investigation, Islamic microfinance has a client base of more than 300,000 through 126 operating institutions in 14 countries, and around 80,000 customers are connected with Indonesian co-operative societies. Surprisingly, however, Islamic microfinance holds only a tiny share in Muslim countries. It is expected to be developed further with the due support of government. Indeed, in 2007, the Pakistan government supported Islamic microfinance.

Ledgerwood (1999) stated that microfinance is a tool for the sustainable development of the society. It functions in the following three ways. First, 
microfinance contributes to the broader macroeconomic perspective, essentially in the non-technical aspect. Second, it works primarily in the sphere of financial intermediation, taking a more technological approach and shifting progress towards the micro issues. Third, it is focused on the financial viability of microfinance institutions. Meanwhile, Zeller and Meyer (2002) proposed the theory of microfinance, which operates within the triangle of outreach (reaching to the depth of poverty and poor people as a whole), financial sustainability (meeting the operating and financial costs of the long-term period), and impact (involving no discrimination towards people in the society based on religion, race, cast, culture and values). This is a most successful explanation of MFIs. Armendariz and Morduch (2005) provided a new picture of microfinance with their finding of a gap in the microfinance literature between academics and practitioners. This theory identified the poor people who were saving money and how the institution worked to overcome market failures. It also extended the role of women in microfinance, informal markets and management initiatives for the successful functioning of microfinance in society. These practices are in place around Asia, Africa and Latin America, and all three issues work upon the economy of microfinance.

\subsubsection{Islamic Microfinance}

Obaidullah (2008) states that Islamic microfinance functions according to two approaches, livelihood and growth enterprises, to alleviate poverty in the member countries of the Islamic development bank. It makes the strategies of microenterprises Shariah-compliant and highlights the thematic issues affecting countries like Bangladesh, Indonesia and Turkey. In Bangladesh there is a greater focus on poverty alleviation through an emphasis on rural development. Indonesia is continually attempting to overcome poverty through the development of microenterprises in its society. The Turkish government, meanwhile, has opted to focus on the financial and non-financial inputs of KOSGEB (small and medium enterprises for the alleviation of poverty in the country). Khan (2008) states that Islamic microfinance is the best theory for addressing the practice of the social development of the nation. Smolo and Ismail (2010) focused on the new microfinance paradigm, i.e. Islamic microfinance, which works on both the eradication of poverty from and the development of society. Theory suggests that conventional microfinance helps needy people, while those in support of the pure religion aspect developed Islamic microfinance for hands-on hand help for the poor and needy people for the society with taking any consideration of the religion, cast, race and culture. And also making the conceptual framework with making the difference between conventional microfinance and Islamic microfinance . Meanwhile, Iqbal and Mirakhor (2012) employed financial inclusion in their study of Islamic finance, which has played a great role in the development of society and the economy.

Ascarya (2014), in presenting empirical views on the topic of sustainable microfinance and Islamic finance, found that the best conventional Grameen model is Koperasi Mitra Dhuafa; the best Islamic Grameen model in Indonesia is KUBE Sejahtera No. 21. Banks are also working on the sustainable 
aspects of microenterprises in Indonesia, i.e. the best conventional rural bank model is BKK Purwodadi and the best Islamic rural bank model is Amanah Ummah. Micro-banking creates wealth for society, with BRI Unit as the best conventional micro-banking unit model; and the best Islamic micro-banking unit model is BSM Warung Mikro. This illustrates how conventional and Islamic microenterprises are working effectively and sustainably in Indonesia. (Ascarya, 2016) proposed a theory based on the holistic approach of Islamic microfinance through financial inclusion and social inclusion. Baitul Maal is the part of this social inclusion that encompasses outreach and sustainability. Baitut Tamwil is the part of financial inclusion that includes the economic and social impacts of society. The case study focused on the integration of Islamic social finance and conventional finance in BMT. It also sought to identify the impact of managing Islamic social funds before and after. Islamic social funds work not only on the microlevel but also on the community level through the Islamic banks (Ascarya, 2018).

\subsection{Previous Studies}

Many previous studies have worked on microfinance mapping. Asaduzzaman (1997) gave credit to microfinance that has worked to alleviate poverty in Bangladesh. Seibel and Parhusip (1998) demonstrated the outreach and sustainability development that took place when Rural Bank Shinta Daya promoted microfinance in Indonesia. Brau and Woller (2004) provided a clearer picture of microfinance, addressing the issues of MFI sustainability, products and services, management practices, clientele targeting, regulation and policy, and impact assessment. Based on Riwayanti (2014), there are two different Islamic financial institutions, BMT and Islamic Rural Bank, which share a common understanding of the development of the social and economic aspects of society in Indonesia. The empowerment of Islamic microfinance has impacted on rural development, social benefits, religious values and poverty alleviation. A number of studies have considered microfinance and Islamic microfinance in Bangladesh, Pakistan, Indonesia, Turkey and many more. This reference research seeks to explore the future of Islamic microfinance in India with reference to the literature review.

\section{METHODOLOGY}

\subsection{Data}

This research paper presents a review of various studies conducted on Islamic microfinance and published in different academic research journals and World Bank reports. An extensive study of 391 research articles was conducted for the purpose of classifying the research papers. Convenience sampling was used to select the research paper for inclusion in the present study.

\subsection{Model Development}

This study of Islamic microfinance developed in three phases. In the first phase, where Islamic microfinance is covered in a wide range of literature reviews, the researchers collected Islamic microfinance data from various journals in an online 
database. The researcher then grouped all of the content into twenty-three main factors. After analysing the first phase, for the second phase the researcher further modified the factors to classify them into ten main areas of content. During the third phase, the remaining ten factors were re-structured into seven factors, i.e. in a meta-analysis. A total of seven factors were therefore finalised for this study. These seven factors were determined on the basis of the strong contribution of scholarly figures and Islamic microfinance practitioners. The factors are as follows: economic development, social benefits, poverty alleviation, religious practices, business enterprises, sustainable development and rural development. All seven factors were analysed using the rank and percentage method.

\subsection{Method}

The researchers read the full paper after the factor that the particular paper was following had been decided. Islamic microfinance deploys the study on the basis of meta-analysis. The factors were selected on the basis of previously conducted studies by different scholars through a meta-analysis. After going through the various research articles, the researcher initially identified twentythree factors for Islamic microfinance. These were then reduced to a final seven factors that are closely associated with Islamic microfinance . (Brau \& Woller 2004) examined literature reviews for the promotion of Islamic microfinance as part of a comprehensive study and extracted factors on Islamic microfinance. Also, (Mukhlisin \& Komalasari, 2018) stated that Islamic microfinance plays an important role in times of crisis and helps in overcoming crises through the sustainable development of society.

\section{RESULTS AND ANALYSIS}

\subsection{Results of the Meta-Analysis}

This section presents the results of the literature review exercise. Table 1 contains a comprehensive bibliography of the research papers as they correspond to the seven previously identified categories. These are seven factors established as the conclusion of the Meta-analysis and are labelled as ED, SB, RV, BE, PA, SD and RD. This is a helpful resource for both academics and practitioners searching for Islamic microfinance in a specific area. 
Table 1.

Literature Review of Islamic Microfinance

Islamic
Microfinance References
Factors

1. Economic Development $(\mathrm{ED}, 73)$

Ahmad (1992), Rahman (1999), Michsel \& Demombynes (2013), Wilson (2007), Hefner (2008), Ahmad (2003), Chapra (1992), El-Gamal (2006), Boualem \& Khan (1995), Khalil et al. (2000), Warde (2000), Weiss (1989), Malik (2005), World Bank (2002), World Bank (2004), Hadavian \& Asghar (1999), Ahmed (2002), Borhan (2000), Sirageldin (2002), El-Ansary \& Waleed (1999), Choudhury (2001) (1997), Siddiqi (1985), Akhtar (1998), Al-ZamZami \& Grace (2000), Chapra (2000), Dhumale \& Sapcanin (1998), Hassan \& Alamgir (2002), Rosly \& Bakar (2003), Ahmed (2006), Dusuki (2008), Obaidullah (2008), Karim et al. (2008), Khan \& Ibrahim (1997), Khan (2008), Patel (2004), SBP (2007), Hayes \& Vogel (1998), Ibrahim (2004), Nicolas (1994), Khan (1986), Usmani (1999), Zaheer \& Hassan (2001), Sait \& Lim (2006), Nelson (2006), Chowdhury (2007), Rahman (2006), Seibel \& Agung (2005), Said et al. (2006), El-Hawary et al.(2005), Iqbal \& Mirakhor (2007), Imady \& Seibel (2003), Lewis (2005), Girish \& Mehta (2003), Al-Harran (1996), Anderson (1988), Sait \& Lim (2005), Imai et al. (2010), Khandker (1998), CGAP (2008), Shylendra (2006), Smolo \& Ismail (2010), Borbora \& Mahanta (2001), Dadhich (2001), Bakhtiari (2006), Meyer \& Nagarajan (2000), Hassan \& Khan (2007), Hassan et al. (2011), Hassan (2011), Kohn \& Jainzik (2006), Rahim (2007), Buckley (1996), Hamid (2005).

2. Social Benefits Schreiner (1999), Parvez (2000), Baydoun \& Willett (1997), World Bank (2002), Ahsan (SB, 62) (2004), Besley \& Coate (1995), Chapra (2000), Ahmed (2006) (2007), Dusuki (2008), Khan \& Ibrahim (1997), Khan (2008), Ibrahim (2004), Nicolas (1994), Siddiqi (1996), Khan et al. (1988), Usmani (1999), Zaheer \& Hassan (2001), Nelson (2006), Chowdhury (2006), Rahman (2006), Seibel \& Agung (2005), Said et al. (2006), El-Hawary et al.(2005), Iqbal \& Abbas (2007), Imady \& Seibel (2003), Lewis (2005), Anderson (1988), Sait \& Lim (2005), Khandker (1998), Shylendra (2006), Smolo \& Ismail (2010), Borbora \& Mahanta (2001), Dadhich (2001), Bakhtiari (2006), Dichter (1996), Montgomery (1996), Hassan \& Khan (2007), Kohn \& Jainzik (2006), Khalil et al. (2000), Warde (2000), Al-Asyqar (1998), Syubair (1998), Buang (2000), Akhtar (1996), Al-Harran (1995), Al-Harran (1990), Hassan, (2011), Abeng (1997), Ali et al. (2008), Ali \& Al-Owaihan (1992), Beekun (1997), Faridi (1995), Rizk (2008), Rice (1999), Yousef (2001), Zaheer \& Hassan (2001), Said et al. (2006), Lewis (2005), Wilson (2007), Naqvi \& Haider (2003), Segrado (2005).

3. Religious Values Chapra (1992), Ibn-Baz (2005), Baydoun \& Willett (1997), El-Gamal (2006), El-Bhasri $(\mathrm{RV}, 45)$ et al. (1997), Badr-El-Din (1997), Khalil et al. (2000), Al-Asyqar (1998), Syubair (1998), Buang (2000), Borhan (2000), Sirageldin (2002), Daud (1988), Siddiqi (1996), Qureshi (1991), Metwally (1997), SBP (2007), Hayes \& Vogel (1998), Ibrahim (2004), Nicolas (1994), Usmani (1998), Zaheer \& Hassan (2001), Sait \& Lim (2006), Nelson (2006), Chowdhury (2006), Rahman (2006), Wilson (2007), Seibel \& Agung (2005), Said et al. (2006), El-Hawary et al.(2005), Iqbal \& Mirakhor (2007), Imady \& Seibel (2003), Anderson (1988), Sait \& Lim (2005), Smolo \& Ismail (2010), Rahim (2007), Ahmed (2002), Akhtar, (1998), Al-Harran (1993), Abdalla (1999), Harper (1994), Ibrahim (1999), Meera \& Razak (2005), Usmani (1999).

4. Business Farooque (2004), Hamid et al. (2001), Karim \& Ahmed (2001), Ahmed (2002), AlEnterprises (BE, Harran (1993), El-Bhasri et al. (1997), Badr-El-Din (1997), Badr-El-Din (2003), Abdalla 41) (1999), Harper (1994), Ibrahim (1999), Ahmed (2002), Choudhury (2001) (1997), Akhtar (1996), Al-Harran (1990) (1995), Hayes \& Vogel (1998), Seibel \& Agung (2005), Sait \& Lim (2005), Berger \& Udell (1998), World Bank (1978), Hamid (2005), Rahman \& Rahim (2007), Khatoon \& Akram (2007), Ledgerwood (1999), Ferro (2005), Wilson (2007), Qureshi (1991), Ziauddin (1991), Akhtar (1998), Al-ZamZami \& Grace (2000), Chapra (2000), Dhumale \& Sapcanin (1998), Ahmed (2006) (2007), Nelson (2006), Dusuki (2008), Rahim (2007), Mohamed (2009). 
Table 1.

Literature Review of Islamic Microfinance (Continued)

\begin{tabular}{|c|c|}
\hline $\begin{array}{l}\text { Islamic } \\
\text { Microfinance } \\
\text { Factors }\end{array}$ & References \\
\hline $\begin{array}{l}\text { 5. Poverty } \\
\text { Alleviation (PA, } \\
40)\end{array}$ & $\begin{array}{l}\text { Chowdhury (2007), Hulme et al. (1996a), Ledgerwood (1999), Mahmood (2006), } \\
\text { Parveen (2001), Rahman (2006), Wood et al. (1997), Seibel (2007), Badr-El-Din } \\
\text { (2003), Wood (1997), Malik (2005), World Bank (2002), Sirageldin (2002), Hassan } \\
\text { \& Alamgir (2002), Rosly \& Bakar (2003), Obaidullah (2008), Patel (2004), Sait \& } \\
\text { Lim (2005), Nelson (2006), Dusuki (2008), Imai et al. (2010), Borbora \& Mahanta } \\
\text { (2001), Dadhich (2001), Bakhtiari (2006), Asaduzzaman (1997), Hulme \& Mosley } \\
\text { (1996), Montgomery (1996), Osmani (1989), Schneider (1997), Khandker (1998), } \\
\text { Lustiq \& Omar (1998), Remenyi \& Quinones (2000), Tinker (2000), Hassan \& } \\
\text { Khan (2007), Widiyanto \& Hendar (2011), Kohn \& Jainzik (2006), Buckley (1996), } \\
\text { Lybbert (2008), Zeller \& Meyer (2002), Meyer \& Nagarajan (2000). }\end{array}$ \\
\hline $\begin{array}{l}\text { 6. Sustainable } \\
\text { Development } \\
(\mathrm{SD}, 24)\end{array}$ & $\begin{array}{l}\text { Alam (1999), Ledgerwood (1999), Seibel \& Parhusip, (1998), Wilson (2007), Bennett } \\
\text { et al. (1996), Bennett \& Cuevas (1996), Khan et al. (1988), Sajjad Chowduhry (2006), } \\
\text { Said et al. (2006), Imady \& Seibel (2003), Nelson (2006), Lewis (2005), Al-Harran } \\
\text { (1995), Anderson (1988), Sait \& Lim (2005), Imai et al. (2010), Shylendra (2006), } \\
\text { Borbora \& Mahanta (2001), Dichter (1996), Zeller \& Meyer (2002), Schreiner } \\
\text { (2000), Alam (2010), Rahman (1999), Metwally (1997). }\end{array}$ \\
\hline $\begin{array}{l}\text { 7. Rural } \\
\text { Development } \\
(\mathrm{RD}, 23)\end{array}$ & $\begin{array}{l}\text { Parveen (2001), Mahmood (2006), Rahman (2006), Yaron et al. (1998), Braverman } \\
\text { \& Guasch (1986), Seibel \& Parhusip (1998), Al-Harran (1995), Malik (2005), World } \\
\text { Bank (2002), World Bank (2004), Wilson (2007), Girish \& Mehta (2003), Smolo \& } \\
\text { Ismail (2010), Borbora \& Mahanta (2001), Dadhich (2001), Meyer \& Nagarajan } \\
\text { (2000), Buckley (1996), Frasca (2008), Karim et al. (2008), Jain et al. (2003), Hassan } \\
\text { (1996), CGAP (2008). }\end{array}$ \\
\hline
\end{tabular}

The review of the literature clearly and firmly identified the fact that the metaanalysis depicts economic development as the major factor among the total of seven factors. There is a coliteral relationship between Islamic microfinance and all the factors, with the meta-analysis identifying that all seven factors are interrelated. An equation for Islamic microfinance (IMF) would thus be written as follows.

$$
\mathrm{IMF}=\mathrm{ED}+\mathrm{SB}+\mathrm{RV}+\mathrm{BE}+\mathrm{PA}+\mathrm{SD}+\mathrm{RD}
$$

While all seven factors are present throughout the Islamic microfinance world, this study asserts that all of the factors are linked to each other. 


\subsection{Robustness of the Meta-Analysis \& a Framework of Islamic Microfinance}

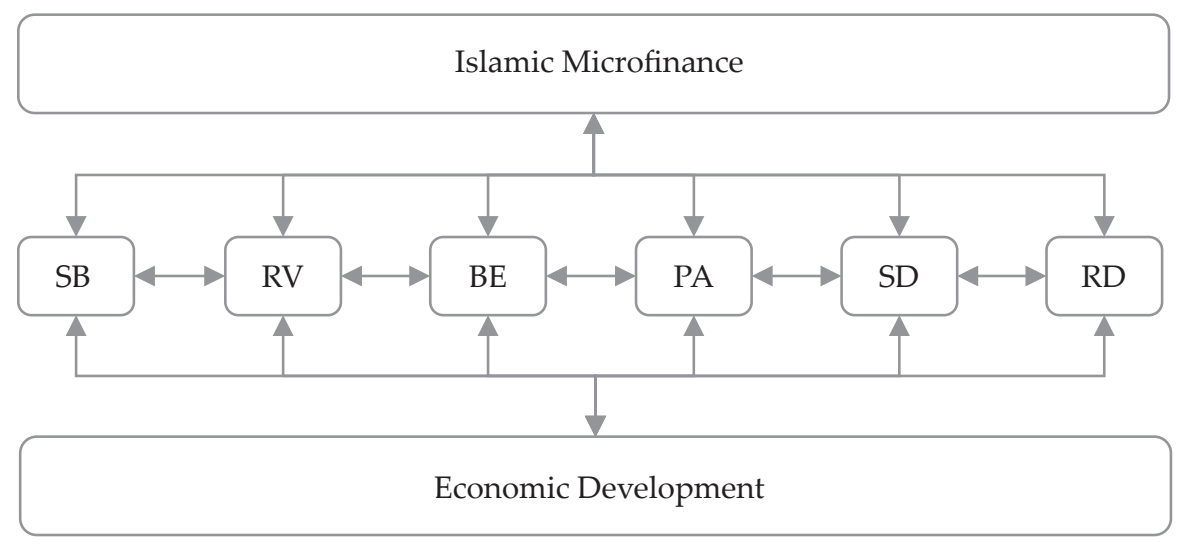

Note: $\mathrm{SB}=$ Social Benefits; $\mathrm{RV}=$ Religious Values; $\mathrm{BE}=$ Business Enterprises; PA = Poverty Alleviation; $\mathrm{SD}=$ Sustainable Development; and RD = Rural Development.

\section{Figure 1. \\ Model of Economic Development through Islamic Microfinance}

\section{a. Economic Development}

Economic development is one of the major factors contained in this study. All of the remaining six factors are co-related clockwise and anti-clockwise or horizontally and vertically. The focus of economic development includes not only Islamic microfinance but also Islamic capital markets, Islamic insurance and Islamic bonds for their respective roles in promoting economic development (Ahmad, 1992; Michsel \& Demombynes, 2013). Islam permits people to engage in halal business (permissible business) that is fruitful for society and also yields economic benefits (Ahmed, 2002; Siddiqi, 1996). Shariah law provides the religious aspect under the consideration of wealth creation of the country (Anderson, 1988; Farooque, 2004; Metwally, 1997). Muhammad Yunus, who was awarded the Nobel Prize in 2006, has often stated, "Small loans, big dreams". In his view, small enterprises contribute more to economic development. Small businesses work with the assistance of the equity and debt market, which shows financial growth as well as economic development (Berger \& Udell, 1998). Islam also permits Musharaka (Equal Partnership), which can be directly linked to sustainability, social empowerment and economic development for the nation (Boualem \& Khan, 1995; Hadavian, 1999). As the great scholar and economist Umar Chapra said, Shariah scholars designed the rule of Shariah law that is ready to accept the challenges of every stage of economy, which includes the cases of both a stable economy and crisis conditions (Chapra, 1992; El-Ansary, 1999). Islamic finance differs from conventional finance with respect to the aspects of interest (Riba), uncertainty and risk (Gharar) and gambling (Maysir). Islamic microfinance aims to support wealth creation, religious values, poverty alleviation and economic development (El-Gamal, 2006; Kohn \& Jainzik, 2006). Islamic finance also tends to become more popular at times of crisis. A very large number of studies have been conducted 
that support the Islamic financial market, which has performed well during times of crisis in the world in comparison to the conventional financial market (Robert, 2008).

\section{b. Social Benefits}

Islamic microfinance improves the local development of food, medical care and education. It creates its own existence, self-respect and dignity, in addition to appreciating the achievement of women (Schreiner, 1999 \& 2000). Mosammat Taslima Begum is a great example of a female entrepreneur. She was the first woman to take a loan (20 US dollars) from Grameen Bank in 1992, buying a goat, and was subsequently elected to serve as a Grameen Bank board member. She also accepted the Nobel Prize on behalf of Grameen Bank's investors and borrowers (2006 ). Islamic microfinance supports socially responsible investment (Segrado, 2005) and also added on the function of profit and loss sharing (Siddiqi, 1985).

\section{c. Religious Values}

Islamic microfinance works not only with regard to interest-free lending and borrowing but also for the overall development of society. Social initiatives are carried out by faith-based organisations (Eberhard, 2008; Mersland, 2007). The World Bank has produced several reports on religion and development issues (Marshall \& Keough, 2004). Islamic microfinance ultimately influences the social empowerment of a country (Anderson, 1988 ; Hayes \& Frank, 1998) and has an emphasis on interest-free processes and minimising risk and uncertainty through the full influence of Shariah rules and regulation (Dunia, 2013). Interest is prohibited in Islamic microfinance, thereby demonstrating that interest is an unnecessary burden on borrowers or exploits borrowers (Chapra, 2000).

\section{d. Business Enterprises}

Islamic microfinance promotes small and medium-size enterprises under permissible sectors; this is basically supported by the musharka (profit and loss sharing) contract (Abdalla, 1999). Islamic microfinance institutions have provided loan facilities to entrepreneurs for poverty alleviation, rural development, sustainability and economic growth. These institutions also work under mudarabha (partnership) contracts (Ahmed, 2002; Akhtar, 1996). Outside of India, Islamic banks function prominently in the development of business enterprises (Badr-ElDin, 1997 \& 2003). Islamic microfinance is also assisting with social empowerment and small enterprises in Bangladesh (Karim \& Ahmed, 2001). The World Bank continuously supports small enterprises for the economic development of the country (World Bank, 1978).

\section{e. Poverty Alleviation}

Poverty alleviation is one of the greatest challenges for the world's population. Prof. Muhammad Yunus, a social entrepreneur, says, "The fact that the poor are alive 
is clear proof of their ability". Islamic microfinance is certainly an effective instrument for poverty alleviation (Khanka, 2010) and it plays a particularly significant role in the alleviation of rural poverty. The United Nations (UN) - the organisation of all the countries of the world - declared 2005 'The UN Year of Micro Credit' (Obaidullah, 2008). Microcredit is thus helping rural and marginalised people across the world to overcome poverty (Asaduzzaman, 1997; Imai et al., 2010). Islamic financial institutions are basically working for the elimination of poverty and the rural development of society (Chowdhury, 2007). Islam is conscious of its zakat fund, wherein zakat is a major concept for poverty alleviation at the level of the locality. As such, Islamic microfinance also uses zakat funds (Badr-El-Din, 2003; Hassan \& Junayed, 2007). Many scholars have views on poverty alleviation wherein microfinance is seen as a fruitful way to support poor and marginalised people within the context of Islamic law (Bakhtiari, 2006; Lustiq \& Omar, 1998; Patel, 2004).

\section{f. Sustainable Development}

Islamic microfinance works as a tool for sustainable community development. If a community is developing, it follows that the nation will also develop (Alam, 2010). Islamic banking thus plays an important role in the promotion of sustainable development (Bennett \& Cuevas, 1996) through support for poor and marginalised peoples (Ledgerwood, 1999). Microcredit initiatives are often regarded as the best ways to maintain the sustainable environment in society (Rahman, 1999). The fatherly and scholarly figure of Islamic finance has provided a viewpoint on Islamic microfinance. He said that Islamic microfinance is the only way to ensure society and business undergo sustainable development (Wilson, 2007). Islamic microfinance also uses zakat (donation) funds, through which some loss-bearing organisations have right to be re-constructed for the existence and proved it again yourself (Schreiner, 2000).

\section{g. Rural Development}

Rural development is a common characteristic of microfinance, which is an effective tool for small farmers and rural development (Al-Harran, 1990). Agriculture credit is facilitated by Islamic financial institutions. It has been shown that this financial system can work for the rural development and poverty alleviation of the nation (Buckley, 1996; Parveen, 2001). Islamic microfinance institutions are proper resources for rural development and poverty reduction because zakat (donations) and waqf (charitable trust) work in parallel (Braverman \& Guasch, 1986; Chowdhury, 2007). Agricultural growth and rural development thus provide clear evidence of the impact that is possible through Islamic microfinance (Malik, 2005). Overall, Asian performance of rural development is high, underpinned by the moral support of microfinance and Islamic microfinance (Meyer \& Nagarajan, 2000). Indeed, governments have announced a number of schemes for the development of agriculture and rural areas through Islamic microfinance institutions and rural banks (Rahman, 2006; Seibel \& Parhusip, 1998; Yaron et al., 1998). According to World Bank reports (World Bank, 2002 \& 2004), the World Bank is ready to promote dynamic rural development for the nation. 


\subsection{Meta-analysis of the Factors Practised in Islamic Microfinance in India}

The Human Welfare Foundation (HWF) is a public charitable trust for the socioeconomic development of weaker sections of society. HWF works on the overall human development of India (Human Welfare Foundation, 2014) while Islamic microfinance societies serve as the tip of the iceberg in India. KHIDMAT is a mutually aided co-operative credit society in Hyderabad (Telagana) established in 1976. It is founded on the belief that "Alone We Can Do little, Together We Can Do So Much", which is used to emphasise the social benefits gained by the nation (Khidmat Foundation, 2018). The Sahulat microfinance society was established in 2010 as a non-political nonprofit and works as a social service organisation. Sahulat works on facilitating and promoting interest-free microfinance institutions with the aim of reducing social disparities. It thus works on alleviating poverty in society (Sahulat Microfinance Society, 2013). BASIX (equity for equity) is an institution that works to promote the livelihoods of rural poor households. It has a client database of 3.5 million, made up of 90 per cent rural and 10 per cent suburban. It works across 17 states, 223 districts and 39,251 villages throughout India and is strongly linked to the promotion of rural development. BASIX also deals with interest-free financing in Nuh, the Mewat District of Haryana, and focuses on the religious value in investment (Basixindia, 2013). The Bait-un-Nas'r urban co-operative society has been a pioneer institution for interest-free banking in India since its establishment in 1976. It operates more than 22 branches throughout Maharashtra State and also benefits from great client support and the economic and social empowerment of the society (BAIT-UN-NAS'R , 2015). The Al-Khair co-operative credit society was established in Patna and has also experimented with interest-free microfinance, making contributions to business enterprises (AL-KHAIR, 2013). The Janseva cooperative credit society was established with the aim of empowering marginalised sections of society and has also opted to conduct its transaction on an interestfree basis. A majority of the co-operative credit societies are registered under the Multi State Co-operative Society Act 2002 and added interest-free products to their ranges with permission to operate in four states, Bihar, Jharkhand, U.P. and Delhi (Janseva Co-operative Creadit Society, 2015). These societies employ practices that reflect the meta-analysis factors in Islamic microfinance in India.

\subsection{Evidence Based Case Study on Bait-un-Nas'r, Mumbai, India}

Islah or Al-Islah (إصـلاح, الإصــلاح , al-'Ișlāh) is an Arabic word that is usually translated as 'reform', in the sense of 'to improve, to better, or to put something into a better position' (Wikipedia, 2019). Islam is also focused on (الرفاه الاجتماعي) Social and Economic welfare. The organisation Bait-un-Nas'r began life in 1976 under the Maharashtra Co-op. Societies Act, 1960. It was registered with the Registrar of Co-operative Societies to function on lines similar to banks but without any interest. It commenced operations as a socio-educational organisation with an initial capital of only 12,000 Indian rupees. Its aim over the 25 years from 1976 to 2000 was to provide interest-free funds to needy people, including the poor, lower-middle and middle-class segments of society. It operated a network of 19 branches throughout the local regions of Mumbai city. It has a share capital of Rs. 1.29 crores and deposits of Rs. 15.15 crores. The society is very well run, 
providing excellent service to its members and depositors (bait-un-nasr, 2019). In providing interest-free banking funds to its customers, Bait-un-Nas'r is evaluated on the basis of economic and sustainability aspects. This study also aims to raise society's awareness of interest-free banking (Shaik \& Waheed, 2019).

\section{a. Suspending Operations of the Organisation}

In 2001, operations were suspended at Bait-un-Nas'r due to the unfortunate circulation of unfounded rumours of bankruptcy. Members and depositors fell victim to false news reports about the society published by a local newspaper. There was consequently a run on the bank as people demanded their money back. Due to the uncontrolled situation, the management decided to return the money held by the bank to its members. As a result, some of its branches were unable to recover their debt, which subsequently became bad debts of the organisation. Various branches were also vandalised and set on fire by depositors. Employees subsequently left the organisation as a result of these drastic situations until, eventually, the organisation was left facing a liquidity crisis, all of which stemmed from some erroneous reporting by the local Urdu newspaper in May 2000. During the same month Bait-un-Nas'r had satisfied all of its depositors with a bank balance of Rs. 2.5 Crores.

The society had expanded operations through its network of 19 branches located in almost all Muslim-dominated areas. These included South Mumbai, Mahim, Bandra (East and West), Dharavi, Kurla (East and West), Cheeta Camp, Govandi, Vikhroli, Andheri, Jogeshwari (East and West) and Malvani, all of which were eventually closed following the suspension of operations.

Table 2.

Past Progress of the Organisation

\begin{tabular}{ccccccc}
\hline $\begin{array}{c}\text { PARTICULARS/ } \\
\text { YEARS }\end{array}$ & $\begin{array}{c}\text { BRANCHES/ } \\
\text { OFFICES }\end{array}$ & $\begin{array}{c}\text { MEMBERS } \\
\text { (No's) }\end{array}$ & $\begin{array}{c}\text { SHARE } \\
\text { CAPITAL } \\
\text { (Rs. in } \\
\text { Thousands) }\end{array}$ & $\begin{array}{c}\text { TOTAL } \\
\text { DEPOSITS } \\
\text { (Rs. in } \\
\text { Thousands) }\end{array}$ & $\begin{array}{c}\text { LOAN } \\
\text { TUROVER } \\
\text { (Rs. in } \\
\text { Thousands) }\end{array}$ & $\begin{array}{c}\text { TOTAL } \\
\text { ASSETS } \\
\text { (Rs. in } \\
\text { Thousands) }\end{array}$ \\
\hline 1977 & 1 & 654 & 26 & 36 & 49 & 0 \\
1978 & 1 & 1133 & 33 & 118 & 208 & 4 \\
1979 & 2 & 2166 & 49 & 325 & 578 & 4 \\
1980 & 3 & 3250 & 70 & 487 & 1027 & 11 \\
1981 & 4 & 4750 & 99 & 762 & 1835 & 13 \\
1982 & 4 & 6820 & 126 & 1171 & 3062 & 13 \\
1983 & 5 & 9012 & 181 & 1730 & 4135 & 19 \\
1984 & 6 & 11237 & 265 & 2529 & 6466 & 84 \\
1985 & 6 & 13649 & 388 & 3686 & 10069 & 492 \\
1986 & 6 & 16992 & 469 & 4294 & 12980 & 495 \\
1987 & 6 & 20356 & 584 & 6191 & 15977 & 705 \\
1988 & 7 & 23039 & 747 & 7951 & 19554 & 1296 \\
1989 & 8 & 26021 & 1159 & 12426 & 27954 & 1484 \\
\hline
\end{tabular}


Table 2.

Past Progress of the Organisation (Continued)

\begin{tabular}{ccccccc}
\hline $\begin{array}{c}\text { PARTICULARS/ } \\
\text { YEARS }\end{array}$ & $\begin{array}{c}\text { BRANCHES/ } \\
\text { OFFICES }\end{array}$ & $\begin{array}{c}\text { MEMBERS } \\
\text { (No's) }\end{array}$ & $\begin{array}{c}\text { SHARE } \\
\text { CAPITAL } \\
\text { (Rs. in } \\
\text { Thousands) }\end{array}$ & $\begin{array}{c}\text { TOTAL } \\
\text { DEPOSITS } \\
\text { (Rs. in } \\
\text { Thousands) }\end{array}$ & $\begin{array}{c}\text { LOAN } \\
\text { TURNOVER } \\
\text { (Rs. in } \\
\text { Thousands) }\end{array}$ & $\begin{array}{c}\text { TOTAL } \\
\text { ASSETS } \\
\text { (Rs. in } \\
\text { Thousands) }\end{array}$ \\
\hline 1990 & 10 & 31359 & 1667 & 16582 & 37205 & 2653 \\
1991 & 11 & 38068 & 2203 & 21242 & 44181 & 4425 \\
1992 & 12 & 47186 & 2862 & 26302 & 58088 & 5497 \\
1993 & 13 & 60282 & 3429 & 33697 & 81163 & 5633 \\
1994 & 15 & 70974 & 4609 & 45201 & 102426 & 7343 \\
1995 & 17 & 86080 & 7454 & 66744 & 147245 & 21002 \\
1996 & 17 & 102331 & 10729 & 90191 & 207398 & 23934 \\
1997 & 18 & 120510 & 13035 & 108580 & 278995 & 25760 \\
1998 & 18 & 137797 & 12993 & 119184 & 324950 & 30405 \\
1999 & 20 & 155050 & 12762 & 124159 & 364810 & 34598 \\
2000 & 20 & 173000 & 12898 & 151491 & 500000 & 43318 \\
\hline
\end{tabular}

Extending beyond the period shown in Table 2, the services of Bait-un-nas'r were suspended for the period 2001-2012. From 2012 onward, the society planned to re-open and focus on repaying those clients whose money had been blocked since the end of 2001.

\section{b. Revival of the Organisation}

In 2012, some members wished to see the society re-start operations so that members could again reap the benefits that they had previously enjoyed. They approached the dysfunctional Board of Directors of the society to seek their cooperation in the mission of re-starting the society. In response to the members' specific request to help in re-starting it, they prepared a detailed scheme for the revival of the society.

The Liquidator and Dy. Registrar agreed to a revival of the society and called a Special General Meeting of the members on 7 November 2012 to present the revival scheme (to pay off the liabilities of the depositors and creditors by selling some of the society's excess real estate assets, barring any branch premises), which was approved by the members present. The members present also elected a new Board of Directors to implement the revival scheme under the chairmanship of Mr. Ibrahim Ansari (Bait-un-Nas'r, 2019). The Dy. Registrar, Co-operative Societies conducted due diligence and issued an Order for Revival of the Society on 21 December 2012, with Mr. Abdul Rashid Shaikh as Administration \& Director Operation and Mr. Farhan Shamsi for the Personnel Dept . (Bait-un-Nas'r, 2019).

The newly elected Board of Directors opened the Head Office of the Society, situated at Mahim. The process of repaying deposits was put into effect from 1 January 2014 in a highly systematic manner. The deposit repayment process has so far been met with an enormous response and over the course of roughly five 
years, all depositors who were able to substantiate their claims have had them settled promptly and in full. The society has thus far been able to smoothly pay back liabilities amounting to around Rs. 3.42 Crores to a substantial number of depositors.

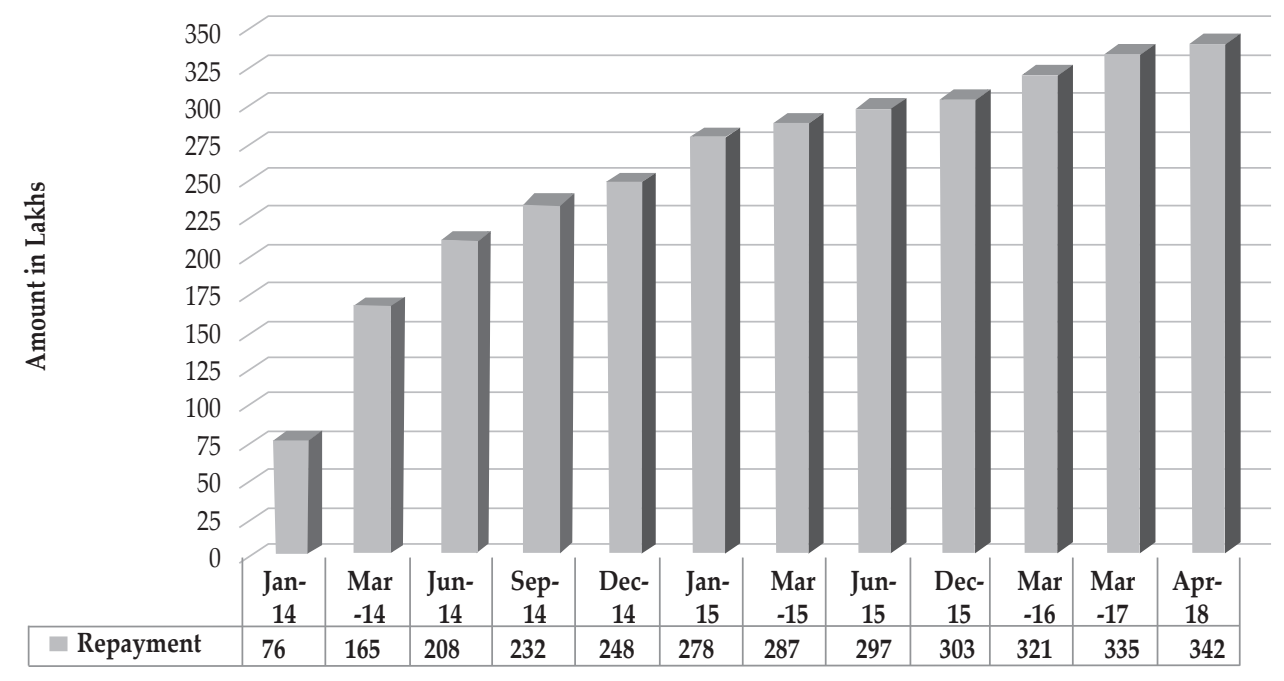

Figure 2.

\section{Repayment of Depositors' Claims}

Figure 2 illustrates the process undertaken by the management, from 1 April 2014, to re-launch its mobilisation and funding activities on an interest-free basis for its members, through a phased re-opening of its branch offices. The process of repaying the outstanding dues of existing depositors also continues, though by now it has been substantially addressed and the outflow of funds has fallen to a small fraction of the initial demand.

\section{c. Old Deposit Repayment Programme}

1. Payments to the depositors of all branches were made centrally from the Head Office in Mahim, Mumbai.

2. Member/depositors were requested to go to the Head Office with their pass book/proof of account/membership.

3. Depositors were also requested to bring proof of identity and address.

4. Following receipt of the KYC updating form and Account-opening form, depositors were issued with a token with a tentative date of payment on which he was to be paid the balance on his account.

5. On the date of payment, depositors were required to bring their passbook and the token issued to them, in exchange for which the payment was released. 
d. Functions of the Organisation: Interest-free loans to needy people.

e. The Islamic Microfinance Model of Bait-un-Nas'r

The organisation model is outlined by way of the flow chart below. It starts with the depositor, followed by collection agents who collect funds from the depositors. Cashiers are then responsible for taking care of the funds and dividends are split into four parts on an equal basis, i.e. loans, overhead expenses, withdrawals and excess cash deposited in the bank account.

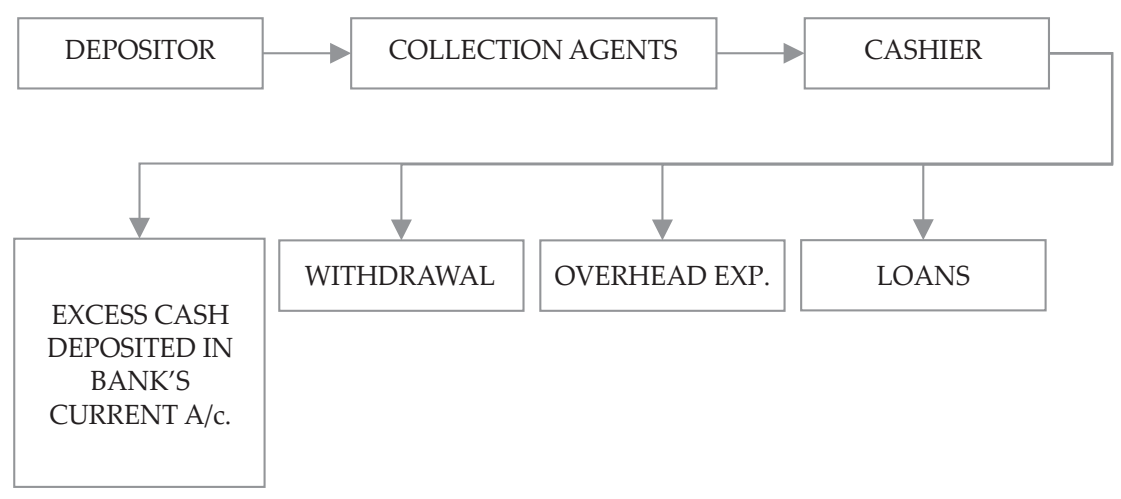

Figure 3.

Islamic Microfinance Model of Bait-un-Nas'r

Figure 4 illustrates the success story of the organisation and shows its funds moving in an upward direction, with the share capital increasing by Rs. 52.81 lakh. There is also an increase in on-the-spot deposits, i.e. Rs. 709.21 Lakh, which indicates that people's trust in the organisation is building. There is also a positive picture with respect to the organisation's saving account, i.e. Rs. 328.84 Lakh and Haj, while Umrah awareness is also increasing in the society, as demonstrated by an increase of Rs. 9.28 Lakh in Haj and Umrah deposits. 


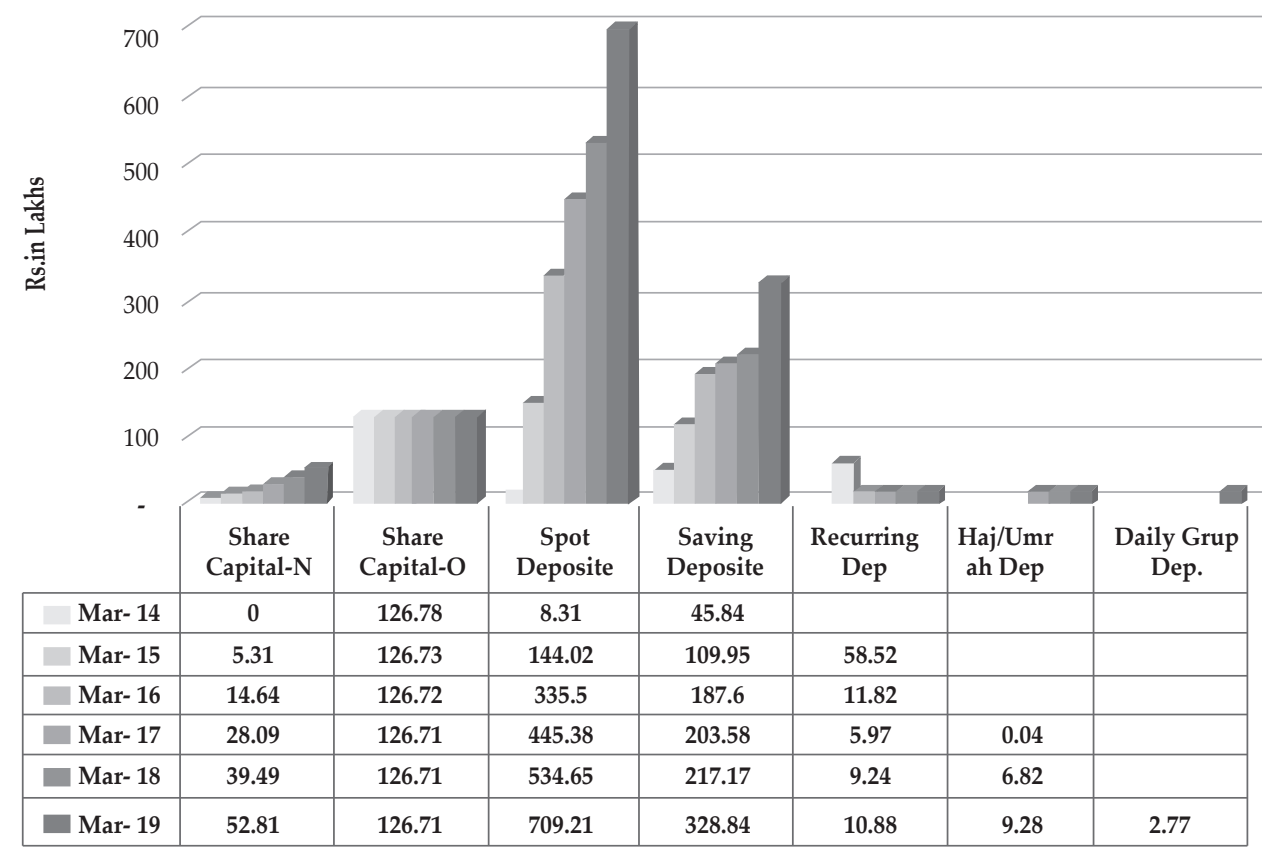

Figure 4.

Growth of Funds

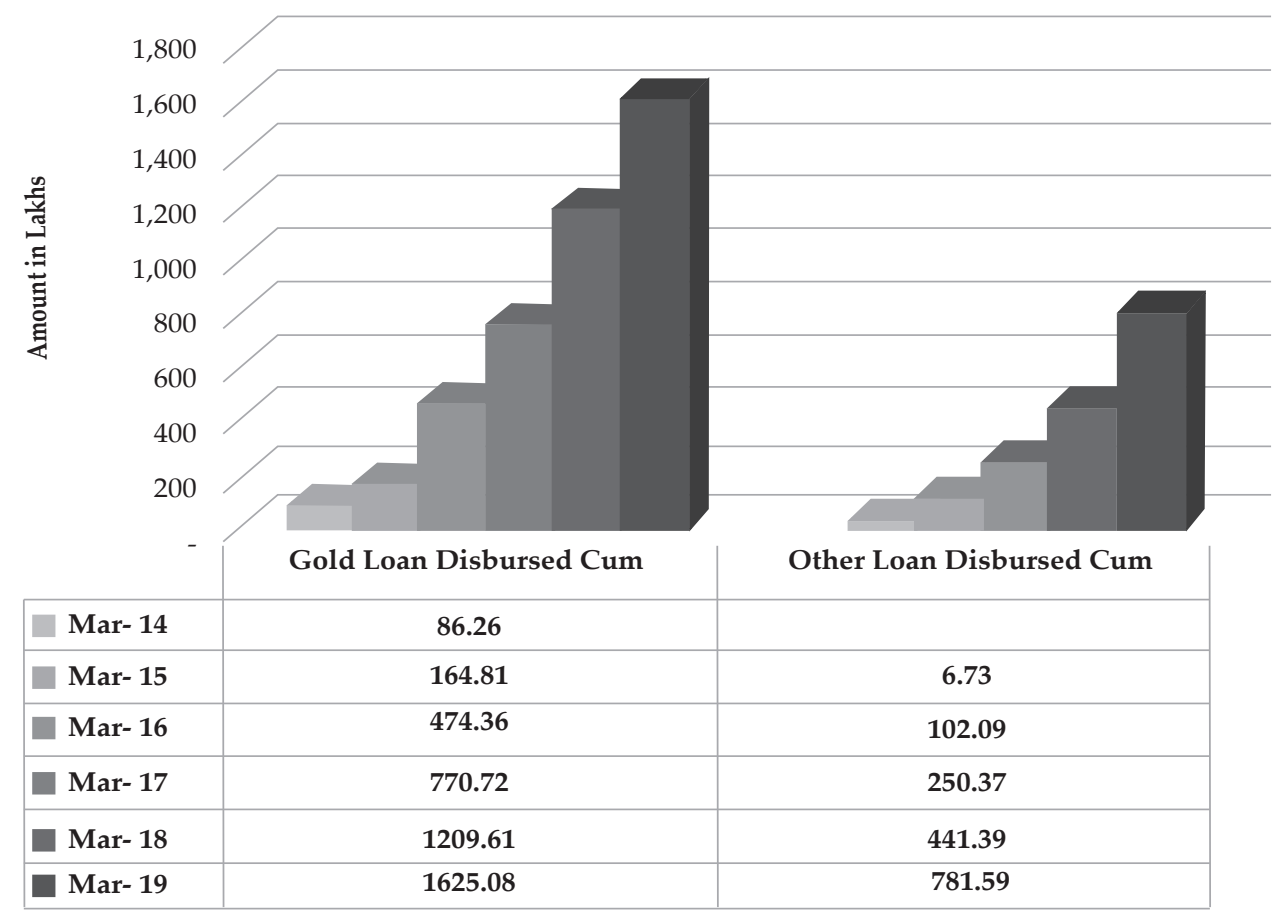

Figure 5.

Growth of Account Holders 
Figure 5 illustrates the trustworthiness of the organisation and shows an increase in the client spot deposit tail, i.e. to 12,822 account holders by March 2019. Therefore, there is a slow and gradual increase in the number of account holders at the organisation.

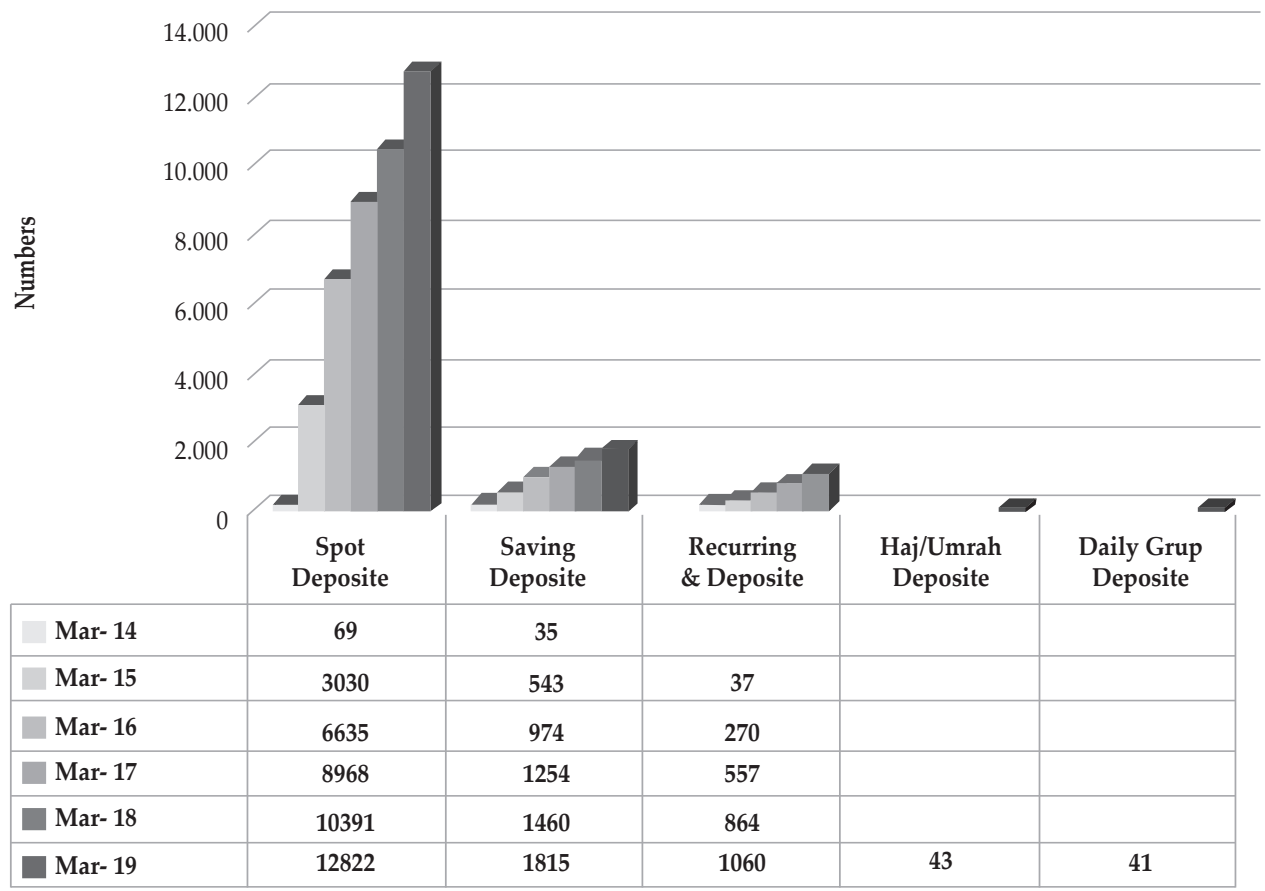

Figure 6.

Cumulative Loans Disbursement

Figure 6 is self-explanatory in nature. It contains data on loan disbursement, which is a very important role of the organisation. Since the organisation has no NPA (Non-Performing Assets), there is a significant relationship between the clients and organisation based on the fact that loan re-payments are made on time. Gold loan disbursement stood at 1,625.08 as of 31 March 2019, while other loan disbursement reached 781.59, thus showing the positive impact of the organisation on the society.

\subsection{Analysis}

\subsubsection{Meta-Analysis}

The meta-analysis is based on the literature review. We found a total of three hundred and eight (308) articles related to Islamic microfinance for the period of observation from 1975 to 2015. Table 3 describes the distribution of the articles according to the meta-analysis. The year with the highest number of articles published was 2006, with the fewest articles published in 1978. 
Table 3.

The Number of Publications by Year

\begin{tabular}{|c|c|c|c|c|c|c|c|c|}
\hline Years & ED & SB & RV & $\mathrm{BE}$ & PA & SD & RD & Total \\
\hline 1978 & & & & I & & & & 1 \\
\hline 1985 & I & & & & & & & 1 \\
\hline 1986 & I & & & & & & I & 2 \\
\hline 1987 & & & & & & & & 0 \\
\hline 1988 & I & II & II & & & II & & 7 \\
\hline 1989 & I & & & & I & & & 2 \\
\hline 1990 & & I & & I & & & & 2 \\
\hline 1991 & & & I & II & & & & 3 \\
\hline 1992 & II & I & I & & & & & 4 \\
\hline 1993 & & & I & I & & & & 2 \\
\hline 1994 & I & I & II & I & & & & 5 \\
\hline 1995 & I & III & I & I & & I & I & 8 \\
\hline 1996 & II & IV & & I & IV & III & II & 16 \\
\hline 1997 & II & IV & $\mathrm{V}$ & III & IV & I & & 19 \\
\hline 1998 & V & IV & V & IV & II & I & II & 23 \\
\hline 1999 & III & II & III & III & I & III & & 15 \\
\hline 2000 & VI & $\mathrm{V}$ & III & II & III & I & I & 21 \\
\hline 2001 & IV & VI & I & III & III & I & III & 21 \\
\hline 2002 & IV & I & II & II & IV & I & I & 15 \\
\hline 2003 & IV & II & I & I & II & I & II & 13 \\
\hline 2004 & III & II & I & I & I & & I & 9 \\
\hline 2005 & VII & VI & VI & IV & II & II & I & 28 \\
\hline 2006 & IX & IX & $\mathrm{V}$ & II & $\mathrm{V}$ & IV & II & 36 \\
\hline 2007 & V & IV & IV & VI & III & I & I & 24 \\
\hline 2008 & VI & IV & & I & III & & IV & 18 \\
\hline 2009 & & & & I & & & & 1 \\
\hline 2010 & II & I & I & & I & II & I & 8 \\
\hline 2011 & II & & & & I & & & 3 \\
\hline 2012 & & & & & & & & 0 \\
\hline 2013 & I & & & & & & & 1 \\
\hline TOTAL & 73 & 62 & 45 & 41 & 40 & 24 & 23 & 308 \\
\hline
\end{tabular}

The meta-analysis resulted in 308 articles published between 1975 and 2015. Table 4 below contains the variables that were extracted from the meta-analysis. 
Table 4.

The Number of Articles By Meta-Analysis

\begin{tabular}{ccccccccc}
\hline Years & ED & SB & RV & BE & PA & SD & RD & TOTAL \\
\hline $1975-1980$ & & & & I & & & & 1 \\
$1981-1985$ & I & & & & & & & 1 \\
$1986-1990$ & III & III & II & I & I & II & I & 13 \\
$1991-1995$ & IV & V & VI & V & & I & I & 22 \\
$1996-2000$ & XVIII & XIX & XVI & XIII & XIV & IX & V & 94 \\
$2001-2005$ & XXII & XVII & XI & XI & XII & V & VIII & 86 \\
$2006-2010$ & XXII & XVIII & X & X & XII & VII & VIII & 87 \\
$2010-2015$ & III & & & & I & & & 4 \\
TOTAL & 73 & 62 & 45 & 41 & 40 & 24 & 23 & 308 \\
\hline
\end{tabular}

The meta-analysis also reveals the factor-wise contribution of the research papers on Islamic microfinance. It is found that the majority of the research papers, 23.70 per cent, considered that Islamic microfinance led to economic development. A total of 20.13 per cent of the research papers considered that Islamic microfinance works as a guide to social benefits, 14.61 per cent of the research papers considered that Islamic microfinance direct to religious values , 13.31 per cent of the research papers considered Islamic microfinance to act as the pilot to business enterprises, 12.99 per cent considered that Islamic microfinance go ahead to poverty alleviation, 7.79 per cent considered that Islamic microfinance shows the way to sustainable development, and 7.47 per cent of the research papers considered that Islamic microfinance provides a means for rural development.

Table 5.

Factor-wise Contribution of Research Articles

\begin{tabular}{lcc}
\hline \multicolumn{1}{c}{ Variables } & No. of Articles & Percentage (\%) \\
\hline Economic Development & 73 & 1,006944444 \\
Social Benefits & 62 & 20.13 \\
Religious Values & 45 & 0,625694444 \\
Business Enterprises & 41 & 13.31 \\
Poverty Alleviation & 40 & 0,56875 \\
Sustainable Development & 24 & 0,346527778 \\
Rural Development & 23 & 07.47 \\
TOTAL & 308 & $100 \%$ \\
\hline
\end{tabular}

\subsubsection{The Case Study}

The case study institution works with the aim of inculcating saving habits among the poor, lower-middle and middle-class families of the community and helping them at the time of need through a system of interest-free credit. From 1976 up to 
2000, Bait-un-Nasr made quite remarkable progress, growing from 654 members and a nil asset value to 1,73,000 members with an asset value of 4.33 crores. During the period 2001-2012, the society's operations were closed down as a result of the publication of false news in the local newspaper, which created an atmosphere of fear and distrust among its depositors and later compelled the society's functionary to return the clients' deposits. In 2012, the society underwent a revival under the chairmanship of Mr. Ibrahim Ansari and restarted operations following an order for the revival of the society on 21 December 2012 by the Deputy Registrar of the co-operative society. The society drew up a systematic plan of action for the repayment of it outstanding deposits, which took effect on 1 January 2014. Up to 31 March 2018, the society had paid back liabilities amounting to Rs 3.42 crores. From 1 April 2014 the management commenced funding activity for members on an interest-free basis, through a phased opening of its branch offices. From our analysis of the data, we observe a roughly 53 per cent increase in the share capital value, along with a multifold jump in the spot deposit amount (from 8.31 lakhs in 2014 to 709.21 lakhs in 2019) and a remarkable growth in saving deposits (from 45.84 lakhs in 2014 to 328.84 lakhs in 2019). The society has grown its members from 69 in 2014 to 12,822 in 2019 . The society is currently expanding day by day in terms of is growth, share capital and client tail.

\section{CONCLUSION AND RECOMMENDATION}

\subsection{Conclusion}

This study has focused on a meta-analysis of the literature on Islamic microfinance. A total of seven factors were extracted from the meta-analysis which demonstrate that Islamic microfinance functions as a social, ethical, economic and faith-based system. Islamic microfinance also contributes to the development of the marginally poor and supported them to grow in both society and business. The study also found that gender differentiation is not a barrier to obtaining financial support from Islamic microfinance institutions (Brau \& Woller, 2004). Nowadays, intuitions are faced with the major challenge posed by financial crises. Islamic microfinance institutions thus have a role to play in terms of helping society as a whole in order to prevent a global financial crisis. Indeed, if all Islamic microfinance intuitions were to work together, they would definitely be able to alleviate both poverty and the impact of a financial crisis around the globe (Mukhlisin \& Komalasari, 2018).

Bait-un-Nasr is a growing institution in the field of Islamic microfinance in India. This is because people make both spot deposits and also deposits for the purposes of saving and Haj and Umrah. Clients have both faith and trust in it and the society is active in various areas of the country. Given its remarkable position in the market in terms of finance and sustainability, the society has evidence of practices for all seven of the factors identified by the meta-analysis.

\subsection{Recommendation}

India is home to the third-largest Muslim population in the world and as a country presents huge opportunities for Islamic financial products. Islamic banking, the Islamic share market, Islamic bonds (Sukuk), Islamic insurance (Takaful) and 
Leasing (Ijrah), as elements of Islamic microfinance, all operate under the umbrella of Shariah law. The biggest objective of Islamic banking is to eliminate interest, which is against the conventional/modern banking in India. Islamic banking and Islamic microfinance are coincide benefits, and Islamic financing techniques are well suited to microfinancing. Islamic microfinance is a secular concept and is not only for the Muslim community but also for other communities.

Regulatory and supervisory concerns play a major role in promoting Islamic microfinance in India. An amendment to the Banking Regulation Act 1949 made it possible to create a system of interest-free banking in India. India's government should seek to open the Islamic finance window within conventional bank as this would also enable secular investors to benefit from interest-free banking and financial activities.

The Insurance Regulatory and Development Authority of India (IRDAI) should permit Islamic takaful (Islamic insurance) in India, by which Indian investors are able to obtain ethical and viable services in the insurance sector.

There should be an amendment to the securities exchange board of India (SEBI), 1992 to permit the development of an Islamic bond market (Sukuk Market) in India. If the India government would allow it, the Islamic bond market would present huge opportunities for investors in India.

Islamic microfinance has led to several factors in India that will be fruitful for the government, industrialists and investors. India is capable of achieving further growth through the growth of Islamic microfinance. Islamic microfinance is the demand of present scenario in India . A regulatory authority is therefore recommended for the purpose of implementing Islamic microfinance in India.

Bait-un-Nasr practises all of the factors that were extracted by the metaanalysis. It has a savings account for the purpose of managing the economic development of the nation. It provides loans to lower-class people to enable them to develop their businesses, which in turn is helping to alleviate poverty in society. Bait-un-Nasr provides the opportunity to save money for Haj and Umrah under the heading religious values. It also enters into partnerships with farmers in their crops and provides interest-free loans. These are the regular functions of Bait-unNasr.

Islamic microfinance continues to grow throughout the world on a daily basis. If the Indian government granted conventional banks the opportunity to open the Islamic finance window, then the Indian economy would grow in parallel. Islamic finance serves a platform from which the international market can grow. The global financial market can also invest in the Indian capital market. FDI and FIIs will also deliver greater benefits for Islamic finance due to its nature as a tool for the sustainable development of the country, as shown by the contribution of Islamic finance to the 2030 agenda for sustainable development. Islamic finance offers the ability to promote a wide range of areas, including a national SDG (sustainable development goals) strategy and infrastructure-related policies related to energy, transport, water and communications. Islamic finance can also enable the development of a framework for aligning environment, social and governance (ESG) and sustainability issues with financial sector practices. A legal and regulatory framework can create the right incentives and instil confidence in investors to support long-term projects. A public-private partnership (PPP) framework would also be beneficial, whereby the private sector develops and 
operates the project for a limited time under a concession agreement. Alongside this, the Islamic capital market should be strengthened to focus on Sukuk, which can then become part of the long-term market. Growth in Islamic non-banking financial institutions is contingent on a robust Islamic capital market that develops Sharia-compliant investment. It also creates synergies that allow Islamic nonbanking institutions and capital markets to grow together.

\section{REFERENCES}

Abdalla, M. G. (1999). Partnership (Musharakah): A New Option for Financing Small Enterprises. Arab Law Quarterly, 14(3), 257-267.

Abeng, T. (1997). Business Ethics in Islamic Context: Perspectives of a Muslim Business Leader. Business Ethics Quarterly, 7(3), 47-54.

Ahmed, H. (2002). Financing Microenterprises: An Analytical Study of Islamic Microfinance Institution. Islamic Economic Studies, 9(2), 27-64.

Ahmed, H. (2006). Frontiers of Islamic Banking: A Synthesis of Social Role and Microfinance. Islamic Research Training Institute, Islamic Development Bank, Jeddah.

Ahmed, H. (2007). Waqf-based Microfinance: Realizing the Social Role of Islamic Finance, International Seminar on "Integrating Awqaf in the Islamic Financial Sector. Singapore.

Ahmad, K. (1992). Economic Development in an Islamic Framework. Leicester, UK: The Islamic Foundation.

Ahsan, M. (2004). Human Development in the Muslim world: From theory to Practice. The Muslim World, 94(2), 181-200.

Ajwani-Ramchandani, R. (2017). The Role of Microfinance in Women's Empowerment: A Comparative Study of Rural \& Urban in India, Emerald, India.

Akhtar, M. R. (1996). Practice and Prospects of Musharaka Financing for Small Enterprises in Pakistan. Journal of Islamic Banking and Finance, 13(3), 7-27.

Akhtar, M. R. (1998). Islamic Microfinance: Credit where Credit is Really Due. Islamic Banker.

Al-Asyqar, M. S. (1998). Bay` al-Murabahah kama Tajrihi alBunuk al-Islamiyyah”. In M. S. Al-Asyqar et al. (Eds.), Buhuth Fiqhiyyah fi Qadaya Iqtisadiyyah Mu'asirah, 2 j. 'Amman: Dar al-Nafa' is, 71- 114.

Al-Harran, S. (1990). Islamic Finance: The Experience of the Sudanese Islamic Bank in Partnership (Musharakah) Financing as a Tool for Rural Development among Small Farmers in Sudan (Unpublished doctoral thesis). Durham University, Durham.

Al-Harran, S. (1993). Islamic Finance: Partnership Financing. Petaling Jaya: Pelanduk Publications.

Al-Harran, S. (1995). Proposal for an Integrated Marketing Model of Musharakah Financing to help Disadvantaged Fishing People in Malaysia. International workshop on Islamic Partnership Financing For Small Enterprise. Organised by the Enterprise Development Centre, Cranfield Scholl of Management of England, Cairo, Egypt.

Al-Khair (2013). Al-Khair Co-Operative Credit Society Limited. Retrieved July 10, 2018 from http://alkhairsociety.com. 
Al-ZamZami, A., \& Grace, L. (2000). Islamic Banking Principles Applied to Microfinance: Case Study of Honeidah Microfinance Programmes, Yemen. United Nations Capital Development Fund (UNCDF), New York, NY.

Alam, N. (2010). Islamic Venture Philanthropy: A Tool for Sustainable Community Development. Social Science Research Network.

Ali, J., \& Al-Owaihan, A. (2008). Islamic Work Ethic: A Critical Review. Cross Cultural Management an International Journal. 15(1), 5-19.

Anderson, G. M. (1988). Mr. Smith and the Preachers: The Economics of Religion in the Wealth of Nations. Journal of Political Economy, 96(5), 1066-88.

Asaduzzaman, M. (1997). Role of Microcredit in Poverty Alleviation. In R.I. Rahman (ed.), Poverty and Development: Bangladesh Perspective, Dhaka: BIDS, (in Bengali).

Ascarya (2014). Sustainable Conventional and Islamic Microfinance Models for Micro Enterprises. ISRA International Journal of Islamic Finance, 6(2), 49-85.

Ascarya (2016). Holistic Financial Inclusion based on Maqashid Shari'ah through Baitul Maal Wat Tamwil. Middle East Insights: Islamic Finance Special, No. 1, Singapore: Middle East Institute -National University of Singapore.

Ascarya (2018). Baitul Maal wat Tamwil (BMT): An Integrated Islamic Social and Commercial Finance Institution in Indonesia. Malaysia: Isra-Thomson Reuters Irti Islamic Commercial Law Report, 2018.

Badr-El-Din, A. I. (1997). Financing Challenges for Small Enterprises - The Experience of Sudanese Islamic Banks. M. Harper Rugby: ITDG Publications, 3-12.

Badr-El-Din, A. I. (2003). Poverty Alleviation via Islamic Banking Finance to Microenterprises (MEs) in Sudan: Some Lessons for Poor Countries. Universita"t Bremen Institute for World Economics and International Management (IWIM) Sudan Economy Research Group Discussion paper no 35.

Bait-un-Nas'r (2015, June 18). Bait-Un-Nas'r, Urban Co-operative Credit Society limited. Retrieved July 9, 2018, from bait-un-nasr.org: http://bait-un-nasr.org/ introduction.php.

Bait-un-Nas'r (2019, Nov 26). Bait-un-nas'r. Retrieved from Board of Directors: http://bait-un-nasr.com/members.php.

Bait-un-Nas'r (2019, Nov 26). Introduction. Retrieved from About Us: http://baitun-nasr.com/introduction.php.

Bakar, D. (1988). Perceptions of Malaysian Corporate Customers towards Islamic Banking Products and Services. International Journal of Islamic Financial Services, Institute of Southeast Asian Studies.

Bakhtiari, S. (2006). Microfinance and Poverty Reduction: Some International Evidence. International Business E Economics Research Journal, 5(12).

Basixindia (2013). Basix Social Enterprise Group. Retrieved July 09, 2018, fromhttp:// www.basixindia.com:http://www.basixindia.com/index.php?option=com content\&task=view\&id=37\&Itemid=51.

Baydoun, N., \& Willett, R. (1997). Islam and Accounting: Ethical Issues in the Presentation of Financial Information. Accounting, Commerce and Finance: The Islamic perspective, 1(1), 1-25.

Bennett, L., \& Cuevas, C. (1996). Sustainable Banking with the Poor. Journal of International Development, 8(2), 145-152. 
Berger, A. N., \& Udell, G.F. (1998). The Economics of Small Business Finance: The Roles of Private Equity and Debt Markets in the Financial Growth Cycle. Journal of Banking and Finance, 22, 613-73.

Borbora, S., \& Mahanta, R. (2001). Micro Credit through Self-help Groups and its impact: A Case of Rashtriya Gramin Bank Vikas Nidhi Credit and Saving Programme in Assam. Indian Journal of Agricultural Economics, 56(3), 449.

Boualem, B., \& Khan T. (1995). Economics of Diminishing Musharakah. Jeddah: Islamic Research and Training Institute IRTI, Islamic Development Bank.

Brau, J. C., \& Woller, G. M. (2004). Microfinance: A Comprehensive Review of the Existing Literature. Journal of Entrepreneurial Finance, Pepperdine University, Graziadio School of Business and Management, 9(1), 1-28.

Braverman, A., \& Guasch, L. (1986). Rural Credit Markets and Institutions in Developing Countries: Lessons for Policy Analysis from Practice and Modern theory. World Development, 14(10/11), 1253-1267.

Buang, A. H. (2000). Studies in the Islamic Law of Contracts: The Prohibition of Gharar. Kuala Lumpur: International Law Book Services.

Buckley, G. (1996). Rural and Agricultural Credit in Malawi. A Study of the Malawi Muzdi Fund and the Smallholder Agricultural Credit Administration. Institute for Development Policy and Management, University of Manchester, United Kingdom.

CGAP (2008). Islamic Microfinance: An Emerging Market Niche. Word Bank.

Chapra, M. U. (1992). Islam and the Economic Challenge. Herndon, VA: The International Institute of Islamic Thought.

Chapra, M. U. (2000). Why has Islam Prohibited Interest: Rationale behind the Prohibition of Interest. Review of Islamic Economics, 9, 5-20.

Chiara, S. (2005). Islamic Microfinance and Socially Responsible Investment. University of Torino MEDA Project, 1-20.

Choudhury, M. A. (1997). The theory of Endogenous Money in Comparative Islamic perspectives. In M. A. Choudhury, Money in Islam (pp. 38-71). London: Routledge.

Choudhury, M. A. (2001). Islamic Venture Capital - A Critical Examination. Journal of Economic Studies, 28(1), 14-33.

Chowdhury, M. A. (2007). The Role of Islamic Financial Institutions in Resource Mobilization and Poverty Alleviation in Bangladesh: An Empirical Study of Rural Development scheme (RDS) of Islamic Bank Bangladesh Ltd. (IBBL), presented in International Seminar on Islamic alternative to Poverty Alleviation: Zakat, Awqaf and Microfinance, Bangladesh, April 21-23, 2007, 1-20.

Dadhich, C. L. (2001). Micro finance - A Panacea for Poverty Alleviation: A Case Study of Oriental Grameen Project in India. Indian Journal of Agricultural Economics, 56(3), 419-43.

Dhumale, R., \& Sapcanin, A. (1998). An Application of Islamic Banking Principles to Microfinance. United Nations Development Program. Regional Bureau for Arab States, New York, N .

Dunia, A. (2013). Risk, Religion, and Islamic Microfinance. The University of San Francisco USF Scholarship: A Digital Repository @ Gleeson Library, Geschke Center,dsaburish@usfca.edu, 
Dusuki, A. W. (2008). Banking for the poor: the Role of Islamic Banking in Microfinance Initiatives. Humanomics: The International Journal of Systems and Ethics, 24(1), 49-66.

El-Ansary, W. (1999). Recovering the Islamic Economic Intellectual Heritage, Problems and Possibilities. Proceedings of the Third Harvard University Forum on Islamic Finance, Cambridge MA: 7-13.

EI-Bhasri, M. E. T., \& Adam, N. A. (1997). Examples of Partnership Financing for Microenterprise - the case of bank. In M. Harper (Ed.), Partnership Financing for Small Enterprise: Some lessons from Islamic Credit Systems. Rugby: ITDG Publications.

El-Gamal, M. (2006). Islamic Finance: Law, Economics and Practice. New York: Cambridge University Press.

Farooque, A. (2004). Micro-enterprise Financing in an Islamic Economic Framework: Bangladesh perspective. Thoughts on Economics, 14(3\&4), 7-19.

Ferro, N. (2005). Value through Diversity: Microfinance and Islamic Finance, and Global Banking. Working Paper, Foundazione Eni Enrico Mattei.

Frasca, A. (2008). A Further Niche Market: Islamic Microfinance in the Middle East and North Africa. Center for Middle Eastern Studies \& McCombs School of Business, University of Texas at Austin.

Girsh, M., \& Mehta, P. (2003). Crop Diversification: An Empirical Analysis on Kangra farms of Himachal Pradesh, India. Asia-Pacific Journal of Rural Development, 13(2).

Hadavian, A. (1999). Gharzul-hasaneh and its Economic Consequences. Islamic Thought \& Cultural Research Center, Ghom: Iran.

Hamid, M., A. (2005). Islamic Banking in Bangladesh: Expectations and Realities. International Conference on Islamic Economics in the 21st Century: Kuala Lumpur, Malaysia, IIUM, 241-281.

Hamid, S. A., \& Ahmad, F. (2001). Performance Evaluation of the Islamic Banking Scheme in Malaysia. Bankers Journal, 118, 19-23.

Hans, S. D., \& Agung, W. D. (2005). Islamic Microfinance in Indonesia. GTZ, Weisbaden, 1-2.

Harper, M. (1994). Musharaka Partnership Financing - An Approach to Venture Capital for Microenterprise. Small Enterprise Development, 5(4), 27-36.

Hassan, M. K., \& Alamgir, D. A. H. (2002). Microfinancial Services and Poverty Alleviation in Bangladesh: A Comparative Analysis of Secular and Islamic NGOs. In M. Iqbal (Ed.), Islamic Economic Institutions and the Elimination of Poverty. Leicester: The Islamic Foundation.

Hassan, M. K., \& Khan, J. M. (2007). Zakat, External Debt and Poverty Reduction Strategy in Bangladesh, Journal of Economic Cooperation, 28(4), 1-38.

Hayes, L., \& Frank, E. (1998). Islamic Law and Finance: Religion, Risk and Return. Arabic and Islamic Law Studies, 16, Kluwer Law International.

Hulme, D., \& Mosley, P. (1996). Finance Against Poverty, 1. London: Routledge.

Human Welfare Foundation (2014, Oct 12). Vision2026. Retrieved 10 July from http://vision2026.org.in/: http://vision2026.org.in.++

Ibn-Baz (2005). Paying Zakah to Earthquake Victim. IslamOnline.Net. Retrieved from http://www.islamonline.net/servlet/Satellite?pagename=Isla mOnlineEnglish.

Ibrahim, W. (1999). La vie, la mort, le marche. Le Monde diplomatique. 
Imai, T., \& Annim, K. (2010). Microfinance and Household Poverty Reduction: New Evidence from India. World Development, 38(12).

Indian Centre for Islamic Finance (2017, Jan 23). Institutions, Retrieved July 12, 2018 from http://www.icif.in: http://www.icif.in/institutions.php

Iqbal, Z., \& Mirakhor, A. (2007). An Introduction to Islamic Finance: Theory and Practice. Singapore: John Wiley and Sons.

Iqbal, Z., \& Mirakhor, A. (2012). Financial inclusion: Inclusion: Islamic Finance Perspective. Journal of Islamic Business and Management, 2(1), 35-64.

Ismail, A. G., \& Smolo, E. (2010). A Theory and Contractual Framework of Islamic Micro-financial Institutions Operations. Journal of Financial Services Marketing, 15(4), 287-295.

Janseva Co-operative Credit Society (2015, June 23). Janseva. Retrieved July 10, 2018, from http://www.janseva.in/: http://www.janseva.in.

John, E. (2008). Attaining Empowerment: The Potential of Religious Social Capital in Microfinance Programs. A Thesis, Georgia State University.

Joni, B. (2000, December 20). Isu-Isu Syariah dalam Sistem Perbankan Islam. Paper presented in Discussion on Islamic Economic, Organized by Department of Sharia and Economic, Academy of Islamic Study, University of Malaya, 2.

Karim, N., Tarazi, M., \& Reille, X. (2008). Islamic Microfinance: An Emerging Market Niche. The Consultative Group to Assist the Poor (CGAP) Focus Note, Washington DC., USA.

Khalil, A., A., \& Colin, R. (2000). Evidence on Agency Contractual Problems in Mudarabah Financing Operations by Islamic Banks. In M. Iqbal and D. T. Llewellyn (Eds.), Islamic Banking and Finance: New Perspectives on Profit Sharing and Rrsk. Cheltenham, UK: Edward Elgar Publishing.

Khan, A. (2008). Islamic Microfinance: Theory, Policy and Practice. Birmingham, UK: Islamic Relief Worldwide.

Khan, M. (1986). Islamic Interest-free Banking: A Theoretical Analysis. International Monetary Fund, Staff Papers, 1-25.

Khandker, S. R. (1998). Fighting Poverty with Microcredit: Experience in Bangladesh. Oxford: Oxford University Press.

Khanka, S. (2010). Microfinance in India: Its Growth, Challenges and Prospects. KAIM Kournal of Management and Research, 2(1), 41-48.

Khidmat Foundation. (2018, July 10), Khidmat Foundation. Retrieved July Tuesday, 2018 from http://khidmatfoundation.com: http://khidmatfoundation.com/ about_us.php.

Kohn, D., \& Jainzik, M. (2006). Microfinance Investment Funds Leveraging Private Capital for Economic Growth and Poverty Reduction, Part III. Springer, 179-191.

Ledgerwood, J. (1999). Sustainable Banking with the poor. In Microfinance handbook - An Institutional and Financial perspective. Washington DC: World Bank.

Lewis, M., \& Algaoud, M. (2001). Islamic Banking. Northampton, MA: Edward Elgar.

Lustiq, N., \& Omar A. (1998). Poverty Reduction, Finance and Development. Quarterly Journal of the IMF, 37(1).

Malik, J. (2005). Agriculture Growth and Rural Poverty: A Review of the Evidence of Asian Development Bank. Pakistan Resident Mission, Working Paper No.2. 
Meera, A. K. M., \& Razak, D. A. (2005). Islamic Home Financing through Musharakah Mutanaqisah and al-Bithaman Ajil Contracts: A Comparative Analysis. Review of Islamic Economics, 9(2).

Metwally, M. (1997). Economic Consequences of Applying Islamic Principles in Muslim Societies. International Journal of Social Economics, 24(7/8/9), 941-957.

Meyer, R., \& Nagarajan, G. (2000). Rural Financial Markets in Asia: Policies, Paradigms, and Performance. New York: Oxford University Press.

Michsel, C., \& Demombynes, G. (2013). The New Transparency in Development Economics: Lessons from the Millennium Villages controversy. Center for Global Development, working paper 342,

Morduch, J., \& Armendariz, B. (2005). The Economics of Microfinance. Cambridge, Mass: MIT Press.

Mukhlisin, M., \& Komalasari, R. (2018). Do you capture the Financial Crisis. Journal of Islamic Monetary Economics and Finance, 3(2), 245-292.

Nelson, R. B. (2006). An Introduction to Copulas (2 ${ }^{\text {nd }}$ edition). New York: Spring Verlag.

Nicholas, A. (1994). Islamic and Western Banking: Part I-major Features, Structural Forms, Comparison with Western Banks, Riba. Middle East Executive Reports. 17(12), 914.

Nimra, K., Michael, T., \& Xavier, R. (2008). Islamic Finance: An Emerging Market Niche. Consultative Group to Assist the Poor (CGAP). Washington, DC, August 2008.

Obaidullah, M. (2008). Role of Microfinance in Poverty Alleviation: Lessons from Experiences in Selected Member Countries. Jeddah, KSA: Islamic Research Training Institute, Islamic Development Bank.

Parveen, A. (2001). Outreach of Micro-credit to Alleviate Rural Poverty-An Evaluation of the Operational Performance of MFIs in Bangladesh (Unpublished master's dissertation). University of Antwerp - RUCA, Belgium, 1-10.

Parvez, Z. (2000). Building New Society: An Islamic Approach to Social Change. Leicester: The Islamic Foundation.

Patel, S. (2004). Takâful and Poverty Alleviation. London: International Cooperative and Mutual Insurance Corporation (ICMIF).

Rahman, A. (1999). Micro-credit Initiatives for Equitable and Sustainable Development: Who pays? World Development, 27(1), 67-80.

Rahman, A. R. A. (2006). The Islamic Microfinance Potential. New Horizon, 162, 9-12.

Rahman, M. M. (2006). Impact of Rural Development Scheme (RDS) of IBBL on the Rural Poor's livelihood in Bangladesh. Islamic Bank Training and Research Academy (IBTRA), Mohammadpur Dhaka, 1-50.

Remenyi, J., \& Quinones, B. (2000). Microfinance and Poverty Alleviation: Case Studies from Asia and the Pacific. New York: Routledge.

Rice, G. (1999). Islamic Ethics and the Implications for business. Journal of Business Ethics, 18, 345-58.

Riwajanti, N. I. (2014). Islamic Microfinance in Indonesia: A Comparative Analysis between Islamic Financial Cooperative (BMT) and Shari'ah Rural Bank (BPRS) on Experiences, Challenges, Prospects, and Roles in Developing Microenterprises. Bulletin of Indonesian Economic Studies, 50(3), 483-484 . doi: https://doi.org/10.1080/00074918.2014.980385 
Riwajanti, N. I. (2014). Exploring the Role of Islamic Microfinance Institution in Poverty Alleviation through Microenterprises Development, a Case Study of Islamic Financial Cooperative (BMT) in Indonesia. Kyoto Bulletin of Islamic Area Studies, 7, 49-66.

Rizk, R. (2008). Back to basics: an Islamic Perspective on Business and Work Ethics. Social Responsibility Journal, 1, 246-254.

Robert, H. (2008). Ambivalent Embrace: Islamic Economics and Global Capitalism. In J. B. Imber (Ed.), Markets, Morals and Religion (pp. 141-156). New Brunswick: Transaction Publishers.

Rodney, W. (2007). Making Development Assistance Sustainable through Islamic Microfinance. International Islamic University of Malaysia (IIUM) Journal of Economics and Management, 15(2), 197-217.

Rosly, A., \& Bakar, M. (2003). Performance of Islamic and Mainstream Banks in Malaysia. International Journal of Social Economics, 30(12), 1249-65.

Roy, M. (2007). The Effect of Religion in Development Efforts - Evidence from the Microfinance Industry and a Research Agenda. University of Agder, Kristiansand, Norway.

Saad, M. (2010). Achieving Human Development Objectives through Microfinance Institution: The case of Amanah Ikhtiar Malaysia. Journal of Islamic Economics, Banking and Finance (JIEBF), 14-28.

Sadiq, A., \& Tasmin, R. (2016). The Role of Islamic Micro-finance in Enhancing Human Development in Muslim Countries. Journal of Islamic Finance, 53-62.

Sahulat Microfinance Society (2013, August 24). Retrieved June 23, 2018, from sahulat.org: http://sahulat.org/index.php/en/

Said, P., Shafqat, M., \& Rehman, Z. (2006). Draft Guidelines for Provision of Islamic Microfinance Services and Products by Financial Institutions. State Bank of Pakistan, Karachi, 1-11.

Sajjad, C. (2006). Creating an Islamic Microfinance Model: The Missing Dimension. Dinar Standard: Business Strategies for the Muslim World, November 18th 2006. www.dinarstandard.com/finance/ MocroFinance111806.htm

Schreiner, M. (1999). Aspects of Outreach: A Framework for Discussion of the Social Benefits of Microfinance. Journal of International Development, Retrieved from http://www.gwbweb.wustl.edu/users.

Schreiner, M. (2000). Ways Donors can help the Evolution of Sustainable Microfinance Organizations, Savings and Development. Center for Social Development Working Paper No. 99-3, Washington University in St. Louis, www.microfinance.com, 24 (4), 423-37.

Segrado, C. (2005). Islamic Microfinance and Socially Responsible Investments: A Case Study. University of Torino.

Seibel, H., D., \& Parhusip, U. (1998). Rural Bank Shinta Daya: Attaining Outreach with Sustainability - a Case Study of a Private Microfinance Institution in Indonesia. IDS Bulletin, 29(4).

Shaik , M., \& Waheed, K. (2019). Interest-free Microfinance in India: a Case Study of Bait-un-Nasr Urban Cooperative Credit Society, ISRA International Journal of Islamic Finance. doi: https://doi.org/10.1108/IJIF-10-2018-0114.

Shylendra, H. S. (2006). Microfinance Institutions in Andhra Pradesh: Crisis and Diagnosis. Economic and Political Weekly. 
Siddiqi, M. (1985). Partnership and Profit-sharing in Islamic law. Leicester, U.K.: The Islamic Foundation.

Siddiqi, N. (1996). Role of the State in the Economy: An Islamic perspective. Leicester, U.K: The Islamic Foundation.

Sirageldin, I. (2002). The Elimination of Poverty: Challenges and Islamic Strategies. In M. Iqbal (ed.), Islamic Economic Institution and the Elimination of Poverty. Leicester: The Islamic Foundation.

Siraj, S., \& Hilary, L. (2005). Islamic Credit and Microfinance. Islam, Land and Property Research Series, UN-HABITAT, New York, Paper 8, 1-21.

State Bank of Pakistan (2007). Islamic Banking Sector Review 2003 to 2007. Islamic Banking Department, Islamabad.

Stephanie, N. (2006). Microfinance: the Opportunity for Islamic Banks. Islamic Finance News, Kuala Lumpur, 3(43), 16-17.

Syubair, M. U. (1998). al-Mu'amalat al-Maliyyah al-Mu'asirah fi al-Figh al-Islami. Beirut: Dar al-Nafa'is.

Tinker, I. (2000). Alleviating Poverty: Investing in Women's work. Journal of the American Planning Association, 66, 229-242.

Usmani, M. T. (1999). The Concept of Musharakah and its Application as An Islamic Method of Financing. Arab Law Quarterly, 14(3), 203-220.

Warde, I. (2000). Islamic Finance in the Global Economy. Edinburgh: Edinburgh University Press.

Weiss, W. M. (1989). The Bazaar: Markets and Merchants of the Islamic world. London: Thames and Hudson.

Wikipedia (2019, Nov 26). Islah, Retrieved from en.wikipedia.org: https:// en.wikipedia.org/wiki/Islah.

World Bank (1978). Employment and Development of Small Enterprises. Sector policy paper. Washington, DC: World Bank.

World Bank (2002). Pakistan - Poverty Assessment: Poverty in Pakistan: Vulnerabilities, Social Gaps and Rural Dynamics. Poverty Reduction and Economic Management Sector Unit, South Asia Region. Washington: DC, Report No. 24296-PAK.

World Bank (2004). Pakistan - Rural Factor Markets: Policy Reforms for Growth and Equity. Rural Development Unit, South Asia Region. Washington: DC. Report No. 30381-PAK.

Yaron, J., McDonald, B., \& Charitonenko, S. (1998). Promoting Efficient Rural Financial Intermediation. intermediation. The World Bank Research Observer, 13(2), 147-170.

Zaheer, T. S., \& Hassan, M. K. (2001). A Comparative Literature Survey of Islamic Finance and Banking. Retrieved from: https://ssrn.com/ abstract=3263061 or http://dx.doi.org/10.2139/ssrn.3263061

Zeller, M., \& Meyer, R. (2002). The Triangle of Microfinance: Financial Sustainability, Outreach, and Impact. Baltimore, MD: John Hopkins University Press. 